\title{
The energy and nutritional demand of the parasitic life of the mite Varroa destructor
}

\author{
Assegid GAREDEW ${ }^{\mathrm{a}}$, Erik SCHMOLZ ${ }^{\mathrm{a} *}$, Ingolf LAMPRECHT ${ }^{\mathrm{b}}$ \\ ${ }^{a}$ Free University of Berlin, Institute of Zoology, Königin-Luise-Strasse 1-3, 14195 Berlin, Germany \\ ${ }^{b}$ Free University of Berlin, Institute of Animal Physiology, Ehrenbergstrasse 26-28, 14195 Berlin, Germany
}

(Received 7 July 2002; revised 24 November 2003; accepted 8 December 2003)

\begin{abstract}
The energy metabolism and nutritional demand of the ectoparasitic mite Varroa destructor Anderson and Trueman was investigated by calorimetry, respirometry and resource utilization rate. Mites from different sexes and developmental stages of the western honeybee Apis mellifera were monitored in the absence of the host. Energy metabolism of the mites, calculated from the rate of heat production, was an insignificant factor in the cause of honeybee colony death. The metabolic rates of mites ranged from $1.1 \%$ to $2.4 \%$ of that of the bee pupa depending on the infestation level. But the nutritional demand of the mites was very high, owing to their inefficient metabolic machinery, utilizing up to $25 \%$ of the nutritional reserves of the pupae accumulated in tissue during the larval stage. The feeding of the mites contributes to the malformation and weakening of the bees and eventually of the colony.
\end{abstract}

Varroa destructor / calorimetry / respirometry / heat production rate / host-parasite relationships / Apis mellifera

\section{INTRODUCTION}

The formidable ectoparasitic mite Varroa destructor Anderson and Trueman feeds on the hemolymph of the brood and adults of the western honeybee Apis mellifera $\mathrm{L}$. causing damage to the bees. The extent of harm is directly proportional to the degree of infestation. V. destructor parasitism may involve different mechanisms of weakening and obliterating of the honeybee colony. The role of $V$. destructor as a vector of bacterial and fungal disease (Wiegers, 1986, Trubin et al., 1987, Glinski and Jarosz, 1988, 1990a, 1990b, 1992, Ball, 1994; Liu, 1996) and as a vector and an inducer of latent viral infection (Haragsim, 1973; Ball, 1983; Ball and Allen, 1986; Wiegers, 1986; Ball, 1996) of the western honeybee A. mellifera. was demonstrated. Ball $(1983,1996)$ stated that $V$. destructor causes open wounds on the surface of the bees or brood through which viral invaders gain access to the hemolymph. Viral infections are commonly suspected to be the primary cause of bee mortality in colonies of A. mellifera severely infested with $V$. destructor. Destruction of host tissue and impairment of the host immune system by the parasite can also induce the development of latent viral infections by releasing infectious agents from damaged tissues and stimulating replication of the viral infectious agent (Wiegers, 1986; Glinski and Jarosz, 1984, 1988). Apart from its role as a vector of bacterial, fungal and viral diseases, it has been demonstrated that even a few mites negatively affect ontogenesis and weight at hatching of the honeybee A. mellifera (Schneider and Drescher, 1987). The researchers also showed that the loss of weight of a bee infested during pupation, compared to non-infested bees, is directly proportional to the number of infesting

\footnotetext{
* Corresponding author: eschmolz@zedat.fu-berlin.de
} 
mites. Infestation of the bee brood with a large number of mites resulted in the formation of adults with malformed wings, underdeveloped / short abdomen (Haragsim, 1973; De Jong et al., 1982; Marcangeli et al., 1992) and underdeveloped hypopharyngeal glands (Schneider and Drescher, 1987). It was also demonstrated that, apart from the lower weight at hatching, honeybees parasitized with $V$. destructor in their pupal stages have reduced life spans compared to unparasitized bees (De Jong et al., 1982; De Jong and De Jong, 1983; Schneider and Drescher, 1987).

The chemical composition of hemolymph of pupae infested with $V$. destructor had lower protein concentration compared to unparasitized pupae (De Jong et al., 1982; Weinberg and Madel, 1985; Kovac and Crailsheim, 1988; Bailey and Ball, 1991). The reduced protein concentration in the hemolymph may indicate why some organs of the honeybees infested in the brood stage are malformed or underdeveloped, since proteins are generally important in organ formation during ontogenesis. Bees that were not infested with mites at the brood stage but that were artificially infested immediately after hatching showed less developed hypopharyngeal glands than non-infested bees (Schneider and Drescher, 1987), demonstrating the energy and nutritional demand the parasite imposes on the immature adult host, which leads to underdevelopment. Comparison of the effect of infestation of $V$. destructor on drone- and worker pupae with equal numbers of mites on the weight at hatching demonstrated a similar weight loss in both sexes indicating that the nutritional value of the hemolymph from workers and drones is the same for the mites (Schneider and Drescher, 1987; De Jong et al., 1982).

Apart from the indirect evidence and notion that the mites are a secondary cause of honeybee colony death, the primary cause being the viral infection transmitted by the mites, no data exists on the energy metabolism of the mites and the pressure they impose on the bees. In this article we will demonstrate calorimetrically and gravimetrically the energy and nutritional demand of $V$. destructor on various developmental stages and sexes of the honeybee $A$. mellifera at different experimental temperatures, and evaluate its implication on the vigour and activity of honeybees. In addition, we will demonstrate the rate of utilization of nutritional reserves by the mites when experimentally starved, and also how long the mites can survive starvation in the absence of their host.

\section{MATERIALS AND METHODS}

\subsection{Survival after starvation and resource utilization by mites}

Tests were conducted to determine how long nonreproducing adult female $V$. destructor could survive in the presence and absence of capped $A$. mellifera drone pupae. These results should show how long a mite survives independent of its host, and the rate of weight loss by the mites could display how much hemolymph they need to suck from their host to maintain their weight and physiological status. In addition to these findings, the results may also tell us how long we can run subsequent calorimetric experiments with mites, since the experiments are performed with starving mites; i.e., in the absence of the host. For these tests, 130 to 190 mites were collected from brown and dark skin drone pupae, weighed using an analytical balance (Sauter, Ebingen, Germany) with a sensitivity of $0.1 \mathrm{mg}$ and incubated at $35^{\circ} \mathrm{C}$ and $60 \pm 5 \%$ R.H. for $1,6,12,18,24$, 30 , or $36 \mathrm{~h}$ in a Petri dish without pupae, or with approximately 4 to 6 mites per pupa. At the end of each experiment, the mites were weighed again and immediately frozen for further analysis. For the determination of the change of body fat and dry matter composition relative to starvation time, the frozen mites were thawed and dried at $60{ }^{\circ} \mathrm{C}$ for $96 \mathrm{~h}$ until they reached constant weight and the mean of the final three weights, performed every $12 \mathrm{~h}$, was used in the calculation of percentage dry matter. The dried samples were then homogenised using mortar and pestle. Analysis of the fat composition was done using the Folch method (Folch et al.,1957). Each of these experiments was conducted three times and the mean \pm S.D. values were used in the presentation of results.

\subsection{Calorimetric experiments}

Calorimetric experiments were performed to determine the metabolic rate of $V$. destructor and to evaluate its energy demand from the host. We used isothermal calorimeters of the type Biocalorimeter - B.C.P (Messgeräte Vertrieb, München, Germany) with a sensitivity of $45 \mu \mathrm{V} / \mathrm{mW}$ and a vessel volume of $12 \mathrm{~cm}^{3}$ and a THERMANALYSE Calorimeter (Messgeräte Vertrieb, München, Germany) with a sensitivity of $45 \mu \mathrm{V} / \mathrm{mW}$ and a vessel volume of $15 \mathrm{~cm}^{3}$ 
To evaluate differences in the energy metabolism of mites from different sexes and developmental stages of the same sex, mites were collected from adult workers and from worker- and drone brood cells. Mites were collected from brown eye and older brood by gently opening individual cells containing pupae that were infested but otherwise healthy (not infected with virus). During the collection process, mites were kept in a Petri dish on the corresponding bee pupae to avoid starvation. Newly moulted adult mites, identified by their pale colour, and young mites (nymphs) with relatively smaller size and feeble locomotion were excluded from the experiment. Mites that seemed weak and abnormal were discarded. Collection of mites from adult workers was done by very carefully dislodging them from the surface of the bees with the help of a blunt needle. Though this collection process was very time consuming and tedious, it was a safe method as far as it is done with caution. During the collection of mites from adult workers, the mites were maintained on worker pupae to avoid starvation.

Twenty five to thirty mites (from the mites that were maintained on pupae) were weighed and put into the calorimeter and the heat production rate was recorded for 2 to 3 hours. This time interval for the calorimetric experiments was chosen for technical reasons, mainly due to the thermal equilibration time needed after opening the calorimeter and placing the mites inside, which was not always the same and varied based on several factors. The little difference in the experimental time interval did not affect the result since the latter was extrapolated to rate per hour. At the end of each experiment the mites were weighed again to determine the amount of weight change and to evaluate the rate of utilization of nutritional reserves under starving condition and consequently to elucidate the amount of hemolymph the mites could utilize from their host to maintain their weight and physiological condition. The weight change is presented as percentage wet weight change per mite per hour.

All calorimetric and gravimetric experiments with mites from the different groups were done at $35^{\circ} \mathrm{C}$. In addition to that, mites from drone brood were investigated at $25,30,35,40,45$, and $50{ }^{\circ} \mathrm{C}$ to determine the optimum temperature of mite metabolism and to elucidate the effect of temperature on their metabolic rate and rate of resource utilization. The experimental time with mites at $45{ }^{\circ} \mathrm{C}$ and $50{ }^{\circ} \mathrm{C}$ lasted 1.5 to $2 \mathrm{~h}$.

\subsection{Respirometric experiments}

The respiration rate of mites from drone brood was determined at $25,30,35,40,45$, and $50^{\circ} \mathrm{C}$ using manometric methods. The tests were run in $12 \mathrm{~mL}$ Warburg vessels.. The $\mathrm{CO}_{2}$ produced was absorbed by $400 \mu \mathrm{L}$ of a $4 \% \mathrm{KOH}$ solution in the side arm of the vessel. The mites were prevented from entering the opening into the side arm by a very thin layer ( $1 \mathrm{~mm}$ thick and $0.8 \mathrm{~mm}$ pore size) of porous spongy material that allowed air flow but prevented mite entrance. The measurements began after a temperature equilibration time of $30 \mathrm{~min}$ and recording was done in intervals of $30 \mathrm{~min}$ for 3 to $5 \mathrm{~h}$ (and for 1.5 to $2 \mathrm{~h}$ at 45 and $50^{\circ} \mathrm{C}$ ). The oxygen consumption rates were calculated from the pressure drop in the Warburg vessel with time. Each measurement was done five times (and nine times at $45^{\circ} \mathrm{C}$ ) using 50 to 60 mites per experiment, and the mean \pm S.D. values were used in the presentation of results. The means were compared with those from the calorimetric experiment run at different temperatures.

Finally, the metabolic rate of the mites obtained from different developmental stages of honeybees was compared with that of the corresponding developmental stages of the host from which the mites were collected. Moreover, the contribution of the energetic demand of mites on the deterioration and death of infested colonies was evaluated.

\subsection{Statistical analysis}

Results are presented as mean \pm S.D. values. Statistical tests were performed using the student's test, one way ANOVA, and the Tukey's HSD post hoc test, by using $\alpha=0.05$ as the critical value.

\section{RESULTS}

\subsection{Survival after starvation and resource utilization by mites}

The starvation experiments with mites from drone brood in the absence of the host showed that no mite death was observed during the first six hours. With prolongation of the starvation time, more mites died, with about $22 \%$ of the mites dying within $12 \mathrm{~h}$ and $50 \%$ within $18 \mathrm{~h}$. Only $5 \%$ of the mites were alive after $36 \mathrm{~h}$ of starvation. There was neither death nor loss of weight of mites incubated on drone pupae (control experiment) at least for the $36 \mathrm{~h}$ experimental time. The starving mites lost $48.5 \%$ of their wet weight within the first six hours of starvation time, which is a loss of $8.1 \%$ per starvation hour. The wet weight change of $V$. destructor with starvation time during the calorimetric experiments for 2 to 3 hours also displayed a loss of $8.1 \% \mathrm{~h}^{-1}$. This trend of weight loss did not continue further in the next starvation 


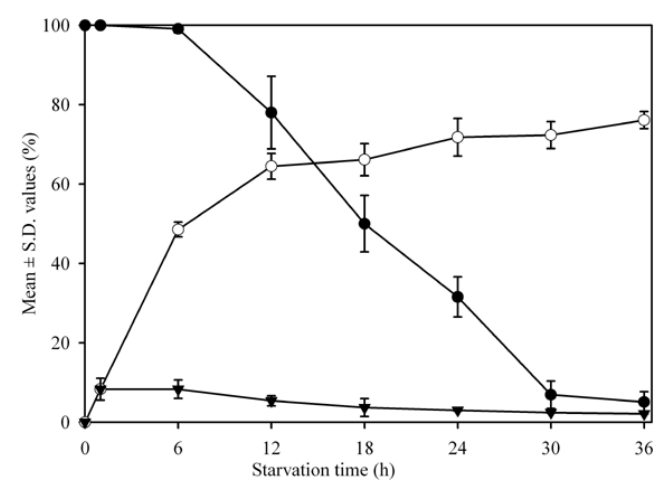

Figure 1. Survival of Varroa destructor mites and the rate of utilization of nutritional reserves under starving conditions in the absence of their host, when the mites were incubated at $35^{\circ} \mathrm{C}$ and $60 \pm$ $5 \%$ R.H. in a Petri dish. Mean percentage of surviving mites (\%), $\bigcirc$ Mean percentage of wet weight loss $(\%), \nabla$ Mean percentage of wet weight loss per hour of starvation (\%).

hours, rather it was reduced with the course of incubation time (Fig. 1). After $36 \mathrm{~h}$ starvation, when $95 \%$ of the mites had already died, the wet weight was reduced by $76 \%$.

\subsection{Calorimetric experiments}

Extrapolation of the wet weight loss of a mite per hour from the weight loss during the 2 to $3 \mathrm{~h}$ starvation time in the calorimetric experiments showed that the percentage weight loss increased with increasing temperature and attained maximum values at $45^{\circ} \mathrm{C}$ of $13.7 \pm$ $1.1 \%, 12.5 \pm 0.6 \%$, and $19.5 \pm 1.9 \%$ mite $^{-1} \mathrm{~h}^{-1}$ for mites from drone brood, worker brood and adult workers, respectively (Fig. 2). Activity of mites at this temperature lasted a maximum of 3 hours and mites were either dead or highly weakened thereafter. The weight change at $50{ }^{\circ} \mathrm{C}$ dropped to zero because the mites died immediately. If we extrapolate the weight loss (mg) at $35^{\circ} \mathrm{C}$ to $24 \mathrm{~h}$, from the percentage weight loss per hour and the wet weight of mites, the mites from drone brood, worker brood and adult workers lost $0.77 \pm 0.06 \mathrm{mg}$, $0.74 \pm 0.09 \mathrm{mg}, 0.89 \pm 0.07 \mathrm{mg}$ per day, respectively. A one way ANOVA showed that there was a significant difference in weight loss of mites from the different sources $(P=0.035)$. A pairwise comparison using the Tukey's HSD

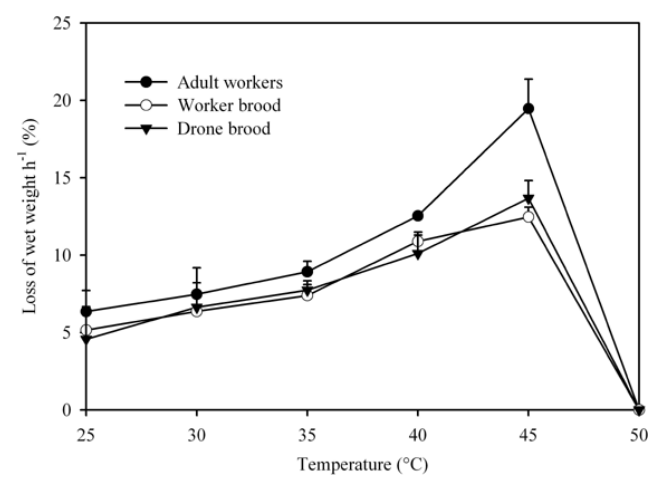

Figure 2. Percentage of wet weight loss (mean \pm S.D.) of the mite Varroa destructor per hour under starving conditions and different experimental temperatures. The data was obtained by starving the mites during calorimetric experiments for 2 to $3 \mathrm{~h}$ at the corresponding temperature. $n=5,25$ to 30 mites per experiment. (Refer to Sect. 2.2 for details of method).

post hoc test showed that there was a significant difference in weight loss between the mites from drone brood and adult workers $(P=$ 0.013 ), and also worker brood and adult workers $(P=0.02)$, but not between mites from drone brood and worker brood $(P=0.25)$. The mites incubated at the above mentioned experimental temperatures and on the corresponding hosts (controls) did not show any weight change with the incubation time. The weight of mites collected from the three groups of bees in their normal physiological conditions and before starvation did not show any significant difference, the values being $407 \pm 38,395 \pm 43,361 \pm$ $63 \mu \mathrm{g}$ for mites from drone brood, worker brood and adult workers, respectively. This could be due to the fact that the brood mites were collected from the late pupal stages (brown and dark skin stages) when there is no oogenesis of the mite.

Chemical analysis results showed that the mean percentage of dry mass remained constant and similar to the control experiments at $68 \%$ regardless of the starvation time. In addition, the relative proportion of the lipid to nonlipid components of the dry mass also remained unaffected, with the lipid components varying between $11.5 \pm 2.5 \%$ and $14.8 \pm 3.7 \%$ and the non-lipid components between $84.8 \pm 6.1 \%$ and $88.0 \pm 17.3 \%$ independent of the starvation time. 


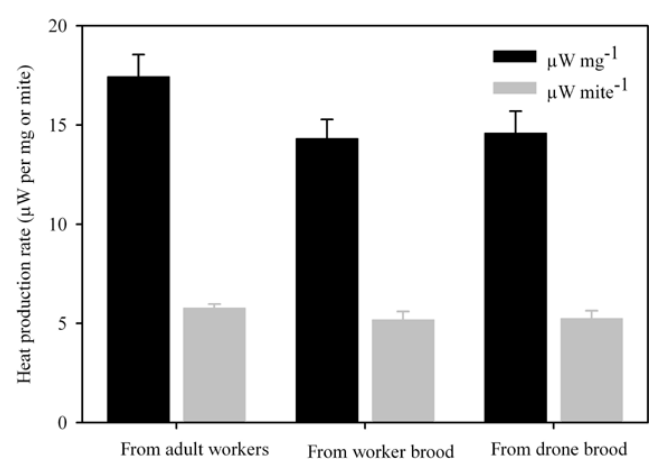

Figure 3. Heat production rate of Varroa destructor mites collected from different sexes and developmental stages of the honeybee $A$. mellifera carnica at $35^{\circ}$ C. 25 to 30 mites per experiments, $\mathrm{n}=5$.

Calorimetric experimental results at $35^{\circ} \mathrm{C}$ indicated that mites collected from worker brood and drone brood had comparable heat production rates, expressed either as $\mu \mathrm{W} \mathrm{mg^{-1 }}$ or $\mu \mathrm{W}$ mite $^{-1}$. Though one way ANOVA showed no difference $(P=0.45)$ in the heat production rate per individual mite $\left(\mu \mathrm{W}\right.$ mite $\left.{ }^{-1}\right)$ between the mites collected from adult workers, drone brood, and worker brood, the same test showed a significant difference $(P=0.024)$ in the mass specific heat production rate $\left(\mu \mathrm{W} \mathrm{mg}^{-1}\right)$ of these mites. The Tukey's HSD post hoc test showed significant differences in the mass specific heat production rate between mites from drone brood and adult workers $(P=0.017)$, and those from worker brood and adult workers $(P=0.023)$ but not those between worker brood and drone brood $(P=0.35)$ (Fig. 3).

Observation of the inner wall of the transparent calorimetric vessels after each experiment displayed several white spots on the otherwise clean Plexiglas vessel. These white spots are faecal matter of the mites, which is considered to be mainly composed of guanine by Sammataro et al. (2000).

\subsection{Respirometric experiments}

Calorimetric and respirometric results of the effect of temperature on metabolic rate of $V$. destructor from drone brood showed identical patterns. Heat production and oxygen consumption rates of mites were low at lower temperatures and rose with increasing tempera- tures, reaching optimum values between $30^{\circ} \mathrm{C}$ and $40{ }^{\circ} \mathrm{C}$. In this temperature range, both curves attained nearly a plateau phase demonstrating little change of metabolic rate with changing temperature. When we compared the $\mathrm{Q}_{10}$ values between $25^{\circ} \mathrm{C}$ and $35^{\circ} \mathrm{C}$ where there was a drastic change of heat production rate, and between 30 and $40^{\circ} \mathrm{C}$, the $\mathrm{Q}_{10}$ value of 2.4 for the former was significantly higher than for the latter of 1.1 (two-tailed $t$-test, $P=$ 0.009 , d.f. $=8$ ). Both heat production and oxygen consumption rates increased and achieved maximum values at $45^{\circ} \mathrm{C}$. These elevated metabolic and oxygen consumption rates at $45^{\circ} \mathrm{C}$ were, however, maintained only for a maximum of $3 \mathrm{~h}$, after which the mites started dying and the rates dropped drastically.

\subsection{Evaluation of the impact of $V$. destructor mites on their host}

To evaluate the energy and nutritional demand of the mites from the brood and to depict the effect of parasitism we considered the following facts. On average, a foundress mite invades a cell containing worker brood ca. $20 \mathrm{~h}$ before cell capping and drone brood ca. $45 \mathrm{~h}$ before, and starts feeding on the brood's reserve food at the bottom of the cell and later on brood's hemolymph (Boot et al., 1991). The post-capping period of the brood lasts 12 and 15 days for worker and drone brood, respectively (Moritz, 1985; Le Conte and Cornuet, 1989). The developmental time of the mite from egg to maturity is 6.9 and 6.2 days for males and females, respectively (Rehm and Ritter, 1989). The first egg is laid $60 \mathrm{~h}$ after cell capping and develops into male and the rest follow in intervals of $30 \mathrm{~h}$ and develop into female mites (Infantidis, 1983). Based on these facts, the feeding time of the mother mite and her offspring is tabulated in Table I. The energy and nutritional demand the mites impose on the brood is calculated from (i) Table II, (ii) the daily energy demand of the mites (extrapolated from Fig. 3), and (iii) the amount of hemolymph the mites suck from the brood (extrapolated from the loss of weight in the absence of the host). If there are two foundress mites instead of one then the energy and nutritional demands of the mites on the brood change, with both values increasing as depicted in Table III. 
Table I. Feeding time of the mother mite and its offsprings on worker and drone brood after invasion of the brood before capping of the cell. (* - Mite does not mature to an adult stage due to a short feeding time.)

\begin{tabular}{ccccc}
\hline & Egg number & $\begin{array}{c}\text { Time (days) after cell } \\
\text { capping at which egg } \\
\text { is laid and its sex }\end{array}$ & $\begin{array}{c}\text { Total time on brood } \\
\text { (days) }\end{array}$ & $\begin{array}{c}\text { Feeding time (days) of the mite } \\
\text { neglecting the feeding period of the } \\
\text { protonymphs i.e. the first 3 days }\end{array}$ \\
\hline In worker brood & Mother mite & & $12.0+0.8=12.8$ & 12.8 \\
& 1 & 2.5 (male) & - & - \\
In drone brood & 3.8 (female) & $12.0-3.8=8.2$ & $8.3-3.0=5.3$ \\
& 3 & 5.0 (female) & $12.0-5.0=7.0$ & $7.0-3.0=4.0$ \\
& Mother mite & 6.3 (female) & $12.0-6.3=5.7$ & $5.8-3.0=2.8^{*}$ \\
& 1 & 2.5 (male) & $15.0+2.0=17.0$ & 17.0 \\
2 & 3.8 (female) & $15.0-3.8=11.2$ & $11.3-3.0=8.3$ \\
& 3 & 5.0 (female) & $15.0-5.0=10.0$ & $10.0-3.0=7.0$ \\
4 & 6.3 (female) & $15.0-6.3=8.7$ & $8.8-3.0=5.8$ \\
& 5 & 7.5 (female) & $15.0-7.5=7.5$ & $7.5-3.0=4.5$ \\
6 & 10.0 (female) & $15.0-10.0=5.0$ & $5.0-3.0=2.0 *$ \\
\hline
\end{tabular}

Table II. Energy and nutritional demand of a mother mite and its offsprings during the developmental time of worker and drone broods. Extrapolated from the energy demand of a mite per day of $471 \mathrm{~mJ}$ (from drone brood), $491 \mathrm{~mJ}$ (from Worker brood), $528 \mathrm{~mJ}$ (from adult workers); weight loss of a mite per day (which is equivalent to the amount of hemolymph a mite sucks from a brood to maintain its weight under nonstarving conditions) $0.85 \mathrm{mg}$ (from adult workers), $0.71 \mathrm{mg}$ (from worker brood), $0.72 \mathrm{mg}$ (from drone brood) and the total feeding time of the mites on the brood.

\begin{tabular}{|c|c|c|c|c|}
\hline & $\begin{array}{l}\text { The nth num- } \\
\text { ber of the mite }\end{array}$ & $\begin{array}{l}\text { Total feeding time } \\
\text { (days) of the } \\
\text { mites on the } \\
\text { brood and its food }\end{array}$ & $\begin{array}{l}\text { Total energy consump- } \\
\text { tion of a mite from the } \\
\text { brood }(\mathrm{J})=\text { total feeding } \\
\text { time }(\text { days }) \times \text { energy } \\
\text { demand mite }{ }^{-1} \text { day }^{-1}\end{array}$ & $\begin{array}{l}\text { Total weight of haemolymph } \\
\text { and brood food consumed } \\
(\mathrm{mg})=\text { extrapolated weight } \\
\left.\text { loss (mg day }{ }^{-1} \text { mite }^{-1}\right) \times \text { total } \\
\text { feeding time (days) }\end{array}$ \\
\hline \multirow[t]{6}{*}{ In worker brood } & Mother mite & 12.8 & 6.3 & 9.1 \\
\hline & 1 & & & \\
\hline & 2 & $8.3-3.0=5.3$ & 2.6 & 3.7 \\
\hline & 3 & $7.0-3.0=4.0$ & 2.0 & 2.8 \\
\hline & 4 & $5.8-3.0=2.8$ & 1.4 & 2.0 \\
\hline & & & Total $=12.3 \mathrm{~J}$ & Total $=17.6 \mathrm{mg}$ \\
\hline \multirow[t]{8}{*}{ In drone brood } & Mother mite & 17.0 & 8.0 & 12.2 \\
\hline & 1 & & & \\
\hline & 2 & $11.3-3.0=8.3$ & 3.9 & 5.9 \\
\hline & 3 & $10.0-3.0=7.0$ & 3.3 & 5.0 \\
\hline & 4 & $8.8-3.0=5.8$ & 2.7 & 4.1 \\
\hline & 5 & $7.5-3.0=4.5$ & 2.0 & 3.2 \\
\hline & 6 & $5.0-3.0=2.0$ & 0.9 & 1.4 \\
\hline & & & Total $=20.8 \mathrm{~J}$ & Total $=32.8 \mathrm{mg}$ \\
\hline
\end{tabular}


Table III. Energy and nutritional demand of two mother mites and their offsprings during the developmental time of worker and drone broods considering that both mother mites are fertile and lay fertilized eggs. Since the maximum infestation rate in the experimental colony was 4 mites per worker brood and 6 mites per drone brood, we limited the evaluation to the mother mites and the first female offsprings in case of worker brood and the mother mites and the two successive female offsprings of each mother mite in case of drone brood. FO1-1: first female offspring of mother mite-1, FO1-2: first female offspring of mother mite-2, FO2-1: second female offspring of mother mite1, FO2-2: second female offspring of mother mite 2.

\begin{tabular}{|c|c|c|c|c|}
\hline & $\begin{array}{c}\text { The nth } \\
\text { number of the } \\
\text { mite }\end{array}$ & $\begin{array}{c}\text { Total feeding } \\
\text { time (days) of the } \\
\text { mite on the brood } \\
\text { and its food }\end{array}$ & $\begin{array}{l}\text { Total energy consump- } \\
\text { tion of the mite from the } \\
\text { brood }(\mathrm{J})=\text { total feeding } \\
\text { time (days) } \times \text { energy } \\
\text { demand } \text { mite }^{-1} \text { day }^{-1}\end{array}$ & $\begin{array}{l}\text { Total weight of hemolymph } \\
\text { and brood food consumed } \\
(\mathrm{mg})=\text { extrapolated weight } \\
\text { loss }\left(\mathrm{mg} \mathrm{day}^{-1}\right) \times \text { total } \\
\text { feeding time (days) }\end{array}$ \\
\hline \multirow[t]{5}{*}{ In Worker brood } & Mother mite1 & 12.8 & 6.3 & 9.1 \\
\hline & Mother mite2 & 12.8 & 6.3 & 9.1 \\
\hline & F.O 1-1 & 5.3 & 2.6 & 3.7 \\
\hline & F.O 1-2 & 5.3 & 2.6 & 3.7 \\
\hline & & & Total $=17.8 \mathrm{~J}$ & Total $=25.6 \mathrm{mg}$ \\
\hline \multirow[t]{7}{*}{ In drone brood } & Mother mite1 & 17.0 & 8.0 & 12.2 \\
\hline & Mother mite2 & 17.0 & 8.0 & 12.2 \\
\hline & F.O1-1 & 8.3 & 3.9 & 5.9 \\
\hline & F.O1-2 & 8.3 & 3.9 & 5.9 \\
\hline & F.O2-1 & 7.0 & 3.3 & 5.0 \\
\hline & F.O 2-2 & 7.0 & 3.3 & 5.0 \\
\hline & & & Total $=30.4 \mathrm{~J}$ & Total $=46.2 \mathrm{mg}$ \\
\hline
\end{tabular}

\section{DISCUSSION}

Though the mites were starving in the absence of their host, death was not observed during the first six hours. This result shows that it is possible to run experiments with $V$. destructor for at least six hours in the absence of their host. For this reason, the calorimetric experiments were limited to 2 to 3 hours, to be on the safe side, even though no drop in the level of the curve was observed while recording the heat production rate for 10 continuous hours. It can be seen in Figure 1 that mites utilized their energy reserves at a higher rate (8.1\% of their wet weight per hour) for the first six hours, and this rate decreased with starvation time. With prolongation of the starvation time they might have run out of nutritional reserves and started dying, as seen with the rapidly declining number of survivor mites. Nearly $95 \%$ of the starving mites died within the first 36 hours of starvation, showing the extent of dependency on their host. The constant proportion of dry mass lost during the starvation time indicated that the loss of weight during incubation was not due to evaporational water loss, but rather to the utilization of nutritional reserves. The steady proportion of lipids to non-lipids, regardless of the starvation time, demonstrated that the mites consumed lipid and non-lipid reserve food proportionally.

The enhanced weight loss of $V$. destructor with ascending temperatures indicated that the metabolic rate and hence utilization of nutritional reserves increased with increasing temperature. This feature is typical of exothermic poikilotherms, as their metabolic rate and body temperature follow the ambient temperature. The increased consumption of nutritional reserves and the higher metabolic rate at temperatures higher than that in the normal beehive environment demonstrated that the energy and nutritional demand of the mites increased with overheating of the brood nest and hence the mites caused more damage than at lower temperatures. The loss of wet weight, heat production, and oxygen consumption rates achieved maximum values at $45{ }^{\circ} \mathrm{C}$ and this activity lasted about three hours, after which the rates dropped drastically. The high rates at this temperature 


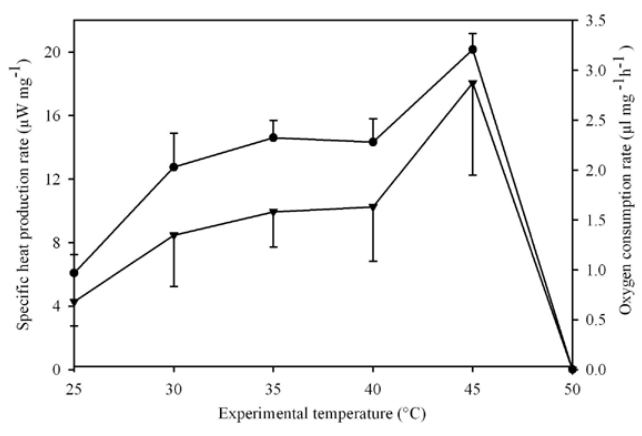

Figure 4. Effect of temperature on the rate of specific heat production, and the rate of oxygen consumption of Varroa destructor mites from drone brood. 25 to 30 and 50 to 60 mites were used per experiment for the calorimetric and respirometric experiments, respectively. $\mathrm{N}=5$ (but $\mathrm{n}=9$ for the respirometric measurements at $45^{\circ} \mathrm{C}$ ), mean \pm S.D. $\bullet$ Heat production rate, $\nabla$ Oxygen consumption rate.

value indicated that the ambient temperature was intolerable for the mites and that they tried to escape, resulting in a higher metabolic rate and increased utilization of nutritional reserves. The plateau phase between $30{ }^{\circ} \mathrm{C}$ and $40{ }^{\circ} \mathrm{C}$ in the heat production and oxygen consumption rates was an indication of the optimum temperature range of $V$. destructor metabolism. Similar patterns obtained with heat production and oxygen consumption rates (Fig. 4) point to the fact that it is possible to use the indirect and cheaper respirometric method in investigations of $V$. destructor metabolism instead of the direct calorimetric approach. Phoretic mites have relatively higher rate of heat production probably because they are fully grown and posses a larger proportion of actively metabolising tissue than nutritional reserves contributing to a higher metabolic rate, compared to the mites from the brood stage. The other possible explanation could be that as an adaptation to their way of life, actively attaching themselves to adult bees to avoid being dislodged which requires a larger amount of energy, the phoretic mites may have an efficient metabolism. Though there was no significant difference between phoretic and brood mites in the rate of heat production per mite and the weight of individual mites, the heat production rate per $\mathrm{mg}$ of phoretic mites was significantly higher than for brood mites. This was because the heat produc- tion rate per phoretic mite was a bit higher while their weight was less, though not significantly, than that of the brood mites.

Though the eight legged protonymphs and male mites feed on the bee brood and cause damage (Sammataro et al., 2000) we have neglected the damage during this phase (the first 3 days of development) to not overestimate the impact of the mites in general. Because the largest number of mites per brood cell observed in our experiments was 4 in worker brood and 6 in drone brood, we have used these as the maxima for the corresponding brood in our calculations. To compare the energy liberation and nutritional reserve consumption of $V$. destructor with that of drone and worker brood during ontogenesis we used the data given in Kösece (1998) and Schmolz et al. (unpublished data). The heat production rate of a drone pupa during the capped developmental stage ranges from 0.7 to $1.9 \mathrm{~mW} \mathrm{pupa}^{-1}$ with the calculated mean heat production rate and the energy use per day being $1.03 \mathrm{~mW} \mathrm{pupa}^{-1}$ and $89 \mathrm{~J} \mathrm{pupa}^{-1}$ respectively. A drone pupa releases $1.34 \mathrm{KJ}$ of energy during the whole ontogenetic phase. The heat production rate of a worker pupa during the capped developmental stage lies between 0.3 and $1.1 \mathrm{~mW}$ pupa $^{-1}$ with the calculated mean heat production rate of $0.5 \mathrm{~mW}$. The mean energy use of a worker pupa per day and during the whole ontogenetic phase amounts to $43.2 \mathrm{~J}$ and $518 \mathrm{~J}$, respectively. The percentage of energy dissipated by $V$. destructor compared to that released by drone pupa ranges from $1.2 \%$ (only three infesting mites) to $1.6 \%$ (six infesting mites), with the mean value being about $1.3 \%$ (four invading mites). And the percentage of energy released by the parasitic mites ranges from $1.2 \%$ of that of worker pupa (with only one infesting mite) to $2.4 \%$ (with four infesting mites), with a mean value of $1.4 \%$ (with 1.4 mites infesting). As can be seen clearly, the energy demand, demonstrated by the heat dissipation rate of a mite, is insignificant even at maximum infestation levels.

The pupal stage of honeybees does not feed and hence depends, for the entire ontogenetic process, on the nutritional reserves accumulated in the tissue during the larval stage. A noninfested larva achieves a maximum weight during the L6 (185 $\pm 17 \mathrm{mg}$ for worker brood) and L7 stage (402 $\pm 19 \mathrm{mg}$ for drone brood) (Kösece, 1998; Schmolz et al., unpublished data). L6 and 
L7 represent the capped larval stages at the 6th and 7 th days of larval development, both at the fifth larval instar. The pupa consumes the nutritional reserves and a freshly hatched worker weighs $115 \pm 7 \mathrm{mg}$ and a drone weighs $256 \pm$ $13 \mathrm{mg}$. Thus, a worker brood and a drone brood utilize $70 \mathrm{mg}$ and $146 \mathrm{mg}$, respectively, during the entire capped developmental stages. If we compare the amount of nutritional reserves consumed by the developing brood (pupa) during ontogenesis with the amount of hemolymph robbed by $V$. destructor, the latter consume $13 \%$ (only one infesting mite) to $25 \%$ (four infesting mites) of the reserve food of the worker brood with a mean value of $15 \%$ (1.4 infesting mites). Considering the case of drone brood, the infesting V. destructor rob $16 \%$ (three infesting mites) to $22 \%$ (six infesting mites) with a mean value of $19 \%$ (four infesting mites), of the nutritional reserves of the nonfeeding pupa.

Energy density analysis of the pupal tissue using bomb calorimetric experiments (Kösece, 1998; Schmolz et al., unpublished data) showed that worker and drone pupae possess $26.4 \mathrm{~J} / \mathrm{mg}$ and $30.1 \mathrm{~J} / \mathrm{mg}$, respectively. Using these values for the amount of hemolymph consumed by the mites and comparing it with the total energy dissipated by the mites during the capped developmental phase of the pupa, we come up with the result that the mites dissipate only $2.2 \%$ of the hemolymph energy they suck from the brood.

The weight loss of workers and drones at hatching, obtained by the back calculation from the resource utilization of the infesting mites during starvation shown in our results, agrees very well with the results of Schneider and Drescher (1987) obtained by directly weighing the bees immediately after hatching. The authors tabulated their results showing that a worker bee parasitized with 1 to 3 and $>3$ mites during the capped brood stage lost $9.6 \%$ and $21.6 \%$, respectively, of its unparasitized wet weight. Considering the weight of freshly hatched drones parasitized during the brood stage, Schneider and Drescher (1987) gave a weight loss of $14.1 \%$ due to infestation with $>3$ mites, which is in good agreement with our result of weight loss of $19 \%$ when a drone was infested with four mites during its capped brood stage.
We can conclude here that the $V$. destructor robs a tremendous amount of the nutritional reserves and hemolymph of the brood, contributing to malformations and improper development of wings, abdomen, legs, and the hypopharyngeal glands (Haragsim, 1973; De Jong et al., 1982; Schneider and Drescher, 1987; Marcangeli et al., 1992). This leads to the development of weak and incapable bees since the nutritional reserves and hemolymph protein are important for ontogenesis and the proper development of the different body parts (Maurizio, 1954; Knox et al., 1971). We do not exclude the possibility that factors other than $V$. destructor infestation could be responsible for the malformation of bees infested with $V$. destructor; but the mites contribute and add to the problem. Their role in the malformation of bees may be demonstrated by comparing the morphology of bees infested with varying number of mites during brood development.

The other fact one could clearly observe with $V$. destructor parasitism is that the mites have a very inefficient system and have to feed continuously to fulfill their energy demand. They excrete most of the hemolymph they ingest without assimilating it and/or metabolise and utilise a very small proportion of the hemolymph assimilated. It is possible that they use some components efficiently, like aphids, but the overall energy use seems highly inefficient. The mites weaken the bee and make it vulnerable to viral and bacterial infections that may be non-infectious or remain latent in non-parasitized situations since the immune system of the non-parasitized host could suppress such infections.

\section{ACKNOWLEDGMENTS}

We would like to thank Dr. Benedict Polaczek for his help in the collection of mites and the DAAD (Deutscher Akademischer Austauschdienst) for the financial support of A.G.

Résumé - Les besoins en énergie et en nourriture du mode de vie parasitaire de l'acarien Varroa destructor. L'acarien ectoparasite Varroa destructor Anderson and Trueman se nourrit de l'hémolymphe des abeilles domestiques (Apis mellifera L.) adultes et de leur couvain et provoque la mort de la colonie. Diverses recherches ont montré le rôle de $V$. destructor dans la transmission des maladies bactériennes, fongiques et virales. Dans la plupart des cas, 
on estime que les infections introduites par les acariens sont la cause primaire de la mort de la colonie. Mis à part cette idée générale, qui sous-estime probablement les besoins en énergie et en nourriture, il n'existe aucune donnée concernant la quantité d'énergie et de nutriments que les acariens dérobent aux abeilles. Dans cet article nous décrivons les besoins en énergie et en nourriture des acariens et, donc, la pression qu'ils exercent sur leur hôte. Des expériences de calorimétrie, de respirométrie (manométrie) et de privation de nourriture ont été menées à différentes températures sur des acariens provenant d'ouvrières adultes et de couvain d'ouvrières et de mâles. Le pourcentage d'énergie calorique dissipée par $V$. destructor, comparée à celle produite par les nymphes de mâles, a varié entre 1,2\% (quatre acariens parasites ou a.p.) à 1,6\% (six a.p.) avec une moyenne de $1,3 \%$ (quatre a.p.). Le pourcentage d'énergie produite par les acariens parasites a varié entre $1,2 \%$ de celle produite par les nymphes d'ouvrières (un seul a.p.) et $2,4 \%$ (quatre a.p.) avec une moyenne de $1,4 \%$ (1,4 a.p.). Il est clair que les besoins énergétiques, calculés d' après le taux de dissipation de chaleur d'un acarien, sont insignifiants même lorsque le niveau d'infestation est maximal. Les abeilles au stade nymphal ne s'alimentent pas et dépendent donc pour le processus complet d'ontogenèse des réserves nutritionnelles accumulées dans les tissus au cours des stades larvaires. Les acariens agissent sur le processus ontogénétique en consommant une partie des réserves nutritionnelles des tissus des nymphes. Si l'on compare l'utilisation des réserves nutritionnelles des nymphes par elles-mêmes d'une part et par les acariens parasites d'autre part, ces derniers consomment entre $13 \%$ (un a.p.) et $25 \%$ (quatre a.p.), avec une moyenne de $15 \%$ (1,4 a.p.). Pour le couvain de mâles $V$. destructor dérobe entre $16 \%$ (3 a.p.) et $22 \%$ (six a.p.), avec une moyenne de $19 \%$ (quatre a.p.) des réserves nutritionnelles des nymphes. S'il y a deux reproductrices au lieu d'une, la quantité de réserves dérobée par les acariens passe à $37 \%$ pour le couvain d'ouvrières parasité par deux reproductrices et une fille de chacune d'elles et $32 \%$ pour le couvain de mâles parasité par deux reproductrices et deux filles de chacune d'elles. Nous pouvons conclure que $V$. destructor dérobe une énorme quantité de réserves nutritionnelles et d'hémolymphe au couvain, contribuant ainsi à des malformations et à un développement incomplet des organes, ce qui donne des abeilles faibles et estropiées. La raison principale pour laquelle les acariens dérobe une grande quantité d'hémolymphe pourrait résider dans le fait qu'ils ont un métabolisme inefficace et qu'ils doivent se nourrir constamment pour répondre à leurs besoins énergétiques. Ce phénomène affaiblit les abeilles et les rend plus vulnérables aux infections virales et bactériennes qui, en conditions de non parasitisme, seraient non infectieuses ou resteraient latentes car combattues par le système immunitaire de l'hôte non parasité.

Varroa destructor / calorimétrie / respirométrie / production de chaleur / relation hôte-parasite
Zusammenfassung - Energie- und Nahrungsbedarf der parasitischen Lebensweise der Milbe Varroa destructor. Die ektoparasitische Milbe $V$. destructor Anderson und Trueman ernährt sich von der Hämolymphe von Adulten sowie der Brut der westlichen Honigbiene Apis mellifera L., was zum Absterben des Bienenvolkes führen kann. Mehrere Untersuchungen haben die Rolle von $V$. destructor als Vektor bakterieller, fungaler und viraler Krankheiten zeigen können. In den meisten Fällen werden die durch die Milben eingebrachten Infektionen als Primärgrund für den Kolonietod von Apis mellifera L. vermutet. Neben dieser allgemeinen Auffassung, die möglicherweise den Energie- und Nahrungsbedarf der Milben unterschätzt, gibt es keine Daten darüber, wie viel Energie und Nährstoffe den Bienen tatsächlich durch die Milben verloren gehen. In dem vorliegenden Artikel klären wir den Energie- und Nahrungsbedarf der Milben und ihren dadurch verursachten Einfluss auf ihren Wirt auf. Kalorimetrische, respirometrische (manometrische) und Hungerexperimente wurden bei verschiedenen Umgebungstemperaturen an Milben, die von adulten Arbeiterinnen und von Drohnen- und Arbeiterinnenbrut stammten, durchgeführt. Die von den Milben abgegebene Wärmeenergie beträgt im Vergleich zur der von Drohnenpuppen zwischen 1,2\% (Befall mit nur 3 Milben) und $1,6 \%$ (Befall mit 6 Milben), mit einem mittleren Wert von 1,3\% (Befall mit 4 Milben). Weiterhin beträgt der Prozentanteil der von den parasitischen Milben abgegebenen Energie zwischen 1,2 \% der Energieabgabe einer Arbeiterinnenpuppe (bei Befall mit nur einer Milbe) und 2,4\% (Befall mit 4 Milben) mit einem mittleren Wert von 1,4\% (Befall mit 1,4 Milben). Es ist bei Betrachtung der niedrigen Wärmeabgabe der Milben klar erkennbar, dass diese selbst bei maximalem Befall alleine durch den durch ihre Wärmeabgabe berechneten Energieverlust keinen signifikanten Anteil am Stoffwechsel der Puppen haben. Honigbienenpuppen nehmen keine Nahrung zu sich und hängen daher für den gesamten ontogenetischen Prozess von den bereits im Larvenstadium im Gewebe gespeicherten Nahrungsreserven ab. Die Milben beeinflussen die ontogenetischen Prozesse durch Entnahme der Nahrungsreserven, die im Gewebe der Puppen gespeichert sind. Ein Vergleich der Nahrungsreserven der Puppe und der auf ihr parasitierenden Milben zeigt, das letztere zwischen $13 \%$ (bei Befall mit einer Milbe) bis zu $25 \%$ (Befall von 4 Milben) mit einem mittleren Wert von $15 \%$ (Befall mit 1.4 Milben) der Nahrungsreserven einer Arbeiterinnenpuppe konsumieren. Bei dem Befall von Drohnenbrut verbraucht $V$. destructor zwischen $16 \%$ (bei Befall mit 3 Milben) und $22 \%$ (Befall mit 6 Milben) mit einem mittleren Wert von $19 \%$ (Befall mit 4 Milben) der Nahrungsreserven. Bei Befall durch zwei anstelle von nur einer Muttermilbe steigt die Menge der durch den Parasiten konsumierten Nahrung auf $37 \%$ bei Arbeiterinnenbrut (Befall mit zwei Muttermilben und jeweils einer Tochter) und $32 \%$ bei Drohnenbrut (Befall mit zwei Muttermilben und jeweils zwei Töchtern) an. Wir schließen aus diesen 
Daten, dass $V$. destructor eine erhebliche Menge an Nahrungsreserven und Hämolymphe verbraucht und damit zu Missbildungen und unvollständigen Bildung von Organen beitragen kann, die in schwachen und verkrüppelten Bienen resultieren. Der Hauptgrund, der dafür verantwortlich ist, dass die Milben eine erhebliche Menge an Hämolymphe konsumieren, könnte in einem relativ ineffizientem Stoffwechsel liegen, der dazu führt dass Milben kontinuierlich Nahrung zu sich nehmen müssen, um ihren Energiebedarf zu decken. Dieses Phänomen schwächt die Bienen und macht sie empfindlicher gegen virale und bakterielle Infektionen, die im nicht parasitierten Zustand nicht infektiös oder nur latent vorhanden sind, da in diesem Falle das Immunsystem des unparasitierten Wirtes solche Infektionen unterdrückt.

\section{Varroa destructor / Kalorimetrie / Respirometrie / Wärmeabgabe / Wirt-Parasit-Beziehung / Apis mellifera}

\section{REFERENCES}

Bailey L., Ball B.V. (1991) Honeybee pathology, 2nd ed., London, Academic Press, p. 193.

Ball B.V. (1983) Der Zusammenhang zwischen V. jacobsoni und Viruserkrankung der Honigbiene, Allg. Dtsch. Imkerztg 17, 177-179.

Ball B.V. (1994) Host-parasite-pathogen interactions, in: New Perspectives on Varroa destructor, Matheson A. (Ed.), Cardiff, UK, IBRA, pp. 5-11.

Ball B.V. (1996) Honeybee viruses: a cause for concern? Bee World 77, 117-119.

Ball B.V., Allen M.F. (1986) The incidence of acute paralysis virus in honeybee colonies infested with the parasitic mite Varroa jacobsoni, in: Fundamental and Applied Aspects on Invertebrate Pathology, Samson R.A., Vlak J.M., Peters D. (Eds.), 4th Int. Colloq. Invertebr. Pathol., p. 151.

Boot J.W., Calis J.N.M., Beetsma J. (1991) Invasion of $V$. destructor mites into honeybee brood cells. When do brood cells attract $V$. destructor mites? Proc. section of experimental and applied entomology of the Netherlands entomological society (N.E.V.) 2, 154-156.

De Jong D., De Jong P.H. (1983) Longevity of Africanized honeybees (Hymenoptera: Apidae) infested by Varroa jacobsoni (Parasitiformes: Varroidae), J. Econ. Entomol. 76, 766-768.

De Jong D., De Jong P.H., Gonçalves L.S. (1982) Weight loss and other damage to developing worker honeybees from infestation with Varroa jacobsoni, J. Apic. Res. 21, 165-167.

Folch J., Lees M., Sloanestanley G.H. (1957) A simple method for the isolation and purification of total lipids from animal tissues, J. Biol. Chem. 226, 497-509.
Gliński Z., Jarosz J. (1984) Alterations in hemolymph proteins of drone honeybee larvae parasitized by Varroa jacobsoni, Apidologie 15, 329-337.

Gliński Z., Jarosz J. (1988) Deleterious effects of Varroajacobsoni on the honeybee, Apiacta 23, 42-52.

Gliński Z., Jarosz J. (1990a) Microorganisms associated fortuitously with Varroa jacobsoni mite, Microbios 62, 59-68.

Gliński Z., Jarosz J. (1990b) Serratia marcescens, artificially contaminating brood and worker honeybees, contaminates the Varroa jacobsoni mite, J. Apic. Res. 29, 107-111.

Gliński Z., Jarosz J. (1992) Varroa jacobsoni as a carrier of bacterial infections to a recipient bee host, Apidologie 23, 25-31.

Haragsim O. (1973) Die Milbe Varroa jacobsoni Oudemans bedroht die Bienenzucht in Europa, Imkerfreund 28, 316-317.

Infantidis M.D. (1983) Ontogenesis of the mite Varroa jacobsoni in worker and drone brood cells, J. Apic. Res. 22, 200-206.

Knox D.A., Shimanuki H., Herbert E.W. (1971) Diet and the longevity of adult honeybees, J. Econ. Entomol. 64, 1415-1416.

Kösece F. (1998) Energiestoffwechsel und Thermoregulation bei eusozialen Insekten unter Berücksichtigung eigener Untersuchungen zur Wärmeproduktion verschiedener Entwicklungsstadien der Honigbiene mit Hilfe der direkten Kalorimetrie, Wissenschaftliche Hausarbeit zur Ersten Wissenschaftlichen Staatsprüfung für das Amt des Studienrats, Freie Universität Berlin.

Kovac H., Crailsheim K. (1988) Lifespan of Apis mellifera carnica Pollm. infested by Varroa jacobsoni Oud. in relation to season and extent of infestation, J. Apic. Res. 27, 230-238.

Le Conte Y., Cornuet J.M. (1989) Variability of the post capping stage duration of the worker brood in three different races of Apis mellifera, in: Cavalloro R. (Ed.), Present status of Varroatosis in Europe and progress in the Varroa destructor mites control, Commission of the European communities, Luxemburg, pp. 171-175.

Liu T. (1996) Varroa destructor mites as carriers of honeybee chalkbrood, Am. Bee J. 136, 655.

Marcangeli J., Monetti L., Fernandez N. (1992) Malformations produced by Varroa jacobsoni on Apis mellifera in the province of Buenos Aires, Argentina, Apidologie 23, 399-402.

Maurizio A. (1954) Pollenernährung und Lebensvorgänge bei der Honigbiene (Apis mellifera L.), Landwirt. Jb. Schweiz 3, 115-183.

Moritz R.F.A. (1985) Heritability of the postcapping stage in Apis mellifera and its relation to Varroatosis resistance, J. Hered. 76, 267-270.

Rehm S.M., Ritter W. (1989) Sequence of sexes in the offspring of Varroa jacobsoni and the resulting 
consequences for the calculation of the developmental period, Apidologie 20, 339-343.

Sammataro D., Gerson U., Needham G. (2000) Parasitic mites of honeybees: life history, implications and impact, Annu. Rev. Entomol. 45, 519-548.

Schneider P., Drescher W. (1987) Einfluss der Parasitierung durch die Milbe Varroa jacobsoni Oud auf das Schlupfgewicht, die Gewichtsentwicklung, die Entwicklung der Hypopharynxdrüsen und die Lebensdauer von Apis mellifera L., Apidologie $18,101-110$.

Trubin A.V., Chernov K.S., Kuchin L.A., Borzenko I.E., Yalina A.G. (1987) European foulbrood: transmission and sensitivity of the causal agents to antibiotics, Veterinariya 8, 46-47 (in Russian).

Weinberg K.P., Madel G. (1985) The influence of the mite Varroa jacobsoni Oud. on the protein concentration and the hemolymph volume of the brood of worker bees and drones of the honeybee Apis mellifera L., Apidologie 16, 421-436.

Wiegers F.P. (1986) Transmission of acute paralysis virus by the honeybee parasite Varroa jacobsoni Oud., in: Fundamental and applied aspects of invertebrate pathology, Samson R.A., Vlak J.M., Peters D. (Eds.), 4th Int. Colloq. Invertebr. Pathol., Wageningen, p. 152. 